\title{
Overexpression of 11 1 -hydroxysteroid dehydrogenase 1 in visceral adipose tissue and underexpression of endothelial nitric oxide synthase in the adrenal cortex of dogs with hyperadrenocorticism
}

\author{
Diego Daniel Miceli ${ }^{1,2}$, Adriana María Belén Abiuso ${ }^{2}$, Patricia Noemi Vidal ${ }^{1}$, María Florencia Gallelli ${ }^{1}$, \\ Omar Pedro Pignataro ${ }^{2}$ and Victor Alejandro Castillo, \\ ${ }^{1}$ Universidad de Buenos Aires, Facultad de Ciencias Veterinarias, Cátedra de Clínica Médica de Pequeños \\ Animales y Hospital Escuela de Medicina Veterinaria, Unidad de Endocrinología, Av. Chorroarín 280, Buenos \\ Aires CP 1427, Argentina \\ ${ }^{2}$ Laboratorio de Endocrinología Molecular y Transducción de Señales, Instituto de Biología y Medicina \\ Experimental - CONICET, Vuelta de Obligado 2490, Buenos Aires CP 1428, Argentina
}

\begin{abstract}
$11 \beta$-Hydroxysteroid dehydrogenase $1(11 \beta$-HSD1) is an enzyme that activates cortisone into cortisol in tissues. Alterations in this enzyme are related to the development of metabolic syndrome, obesity and hyperadrenocorticism (HAC). Endothelial nitric oxide synthase (eNOS) produces nitric oxide and is related to the regulation of adrenal steroidogenesis. The aim of the study was to evaluate 11 -HSD1 and eNOS expression in dogs with HAC. Visceral adipose tissue samples were taken to evaluate $11 \beta$-HSD1 expression by immunohistochemistry and western blotting. In parallel, adrenal gland samples were collected to evaluate eNOS expression by immunohistochemistry. 11 $\beta$-HSD1 expression was significantly higher in the adipocytes of dogs with HAC than in those of the control dogs. eNOS expression in the adrenal cortex (zona fasciculata) was significantly lower in the dogs with HAC than in the control dogs. 11 $\beta$-HSD1 overexpression and eNOS underexpression could play a role in the maintenance of hypercortisolism in dogs with HAC.
\end{abstract}

Keywords: 11ß-HSD1, eNOS, Glucocorticoids, Hyperadrenocorticism.

\section{Introduction}

The actions of glucocorticoids in target tissues are determined by the "nuclear" density of their receptors and the intracellular metabolism of the $11 \beta$ hydroxysteroid dehydrogenase (11 -HSD) isoforms (Chapman et al., 2013). 11ß-HSD is an enzyme that interconverts inactive glucocorticoid compounds (cortisone) into active compounds (cortisol) and vice versa (Seckl and Walker, 2001; Sieber-Ruckstuhl et al., 2007). Two isoforms of the enzyme have been described: 11 $\beta$-HSD1 mainly catalyses the activation of cortisone to cortisol to increase the intracellular cortisol levels and thus amplifies its cellular actions (Morton and Seckl, 2008), whereas 11ß-HSD2 catalyses the reverse reaction (Tomlinson et al., 2004). Given the physiological relevance of both 11 $\beta$-HSD isoforms, they are referred to as "intracellular gate-keepers of tissue glucocorticoid action" (Chapman et al., 2013). $11 \beta$-HSD1 is constitutively expressed in a wide range of tissues, including the liver, adipose tissue, pancreatic islets, bone, gonads, and the nervous system. Additionally, expression of this enzyme can be induced in fibroblasts, smooth and skeletal muscle, and cells of the immune system (Sieber-Ruckstuhl et al., 2007; Ryan et al., 2011; Champan et al., 2013).
Recently, studies on the expression and actions of the $11 \beta$-HSD1 enzyme have become relevant because alterations of the enzyme are associated with metabolic syndrome, obesity (Wake and Walker, 2004; Walker and Andrews, 2006), and the metabolic complications of hyperadrenocorticism (HAC) (Morgan et al., 2016). Various studies have reported that 11 $\beta$-HSD1 expression is increased in the visceral adipose tissues and livers of obese patients (Livingstone et al., 2000; Paulmyer-Lacroix et al., 2002; Candia et al., 2012). This increase in turn increases the local and/or systemic cortisol concentrations, thereby favouring its detrimental effects (Seckl and Walker, 2001; Stulnig and Waldhausl, 2004).

The hypercortisolism of HAC induces a state of insulin resistance that provokes a tendency towards fasting hyperglycemia, hypercholesterolemia, hypertriglyceridemia, abdominal obesity, hepatic steatosis and diabetes mellitus in the most severe cases (Pivonello et al., 2010; Di Dalmazi et al., 2012; Miceli et al., 2014, 2017). There is evidence that local metabolism of glucocorticoids mediated by the $11 \beta$ HSD1 enzyme plays a central role in the development of these complications, which challenges the classical view that active glucocorticoids in general circulation 
represent the most important mode of action of glucocorticoids (Morgan et al., 2016).

Nitric oxide (NO) is a gaseous inorganic free radical whose function as an intracellular messenger has been widely established in a variety of cell types (Nathan, 1992). NO is generated by the oxidation of L-arginine in a reaction catalysed by NO synthase (NOS) (Palmer et al., 1988). NO is involved in numerous biological processes, including smooth muscle relaxation, neurotransmission, cytotoxicity, and nociception (Furchgott and Zawadaki, 1980; Palmer et al., 1987; Garthwaite, 1993; Paradise et al. 2010). Three NOS isoforms have been identified: neuronal (nNOS), endothelial (eNOS), and inducible (iNOS) (Sessa, 1994). eNOS is located in many tissues mainly on the cellular plasma membrane but is also found in the cytosol, nucleus, Golgi apparatus, and mitochondria (Oess et al., 2006).

$\mathrm{NO}$ is involved in the modulation of various endocrine systems (Van Voorhis et al., 1994; Del Punta et al., 1996; Natarajan et al., 2002). Specifically, in the adrenal glands are known to modulate steroidogenesis in rat adrenal zona fasciculata cells (Cymeryng et al., 1998, 2002), in which an inhibitory effect of NO has been demonstrated. Although adrenal steroidogenesis is regulated primarily by adrenocorticotropic hormone $(\mathrm{ACTH})$, the various cell types that compose the structure of the cortex and adrenal medulla secrete compounds that play roles in the fine-tuning of the regulation of adrenal physiology (Hochol et al., 2004; Conconi et al., 2006; Bornstein et al., 2008; Ducsay and Myers, 2011).

Cortisol decreases the plasma NO levels by inhibiting eNOS (Yang and Zhang, 2004; Liu et al., 2009). In dogs with HAC, numerous systemic and metabolic disturbances are generated when the vasodilatory effect of NO is lost, including hypertension, thromboembolism, and blindness (Loscalzo, 1995; Mitchell and Webb, 2002; Luchi et al., 2003; Cabrera Blatter et al., 2012).

The objective of the present study was to evaluate $11 \beta$ HSD1 enzyme expression in visceral adipose tissues and eNOS expression in the adrenal fascicular cortices of dogs with HAC.

\section{Materials and methods}

Detection of 11/-HSD1 expression in visceral adipose tissues

\section{Study material}

Visceral adipose tissues $(\mathrm{n}=16)$ : samples from dogs with pituitary-dependent hyperadrenocorticism (PDH) $(n=8)$ were obtained by necropsy from patients with $\mathrm{PDH}$ who required euthanasia or died for another causes ( 4 females and 4 males; median age of 10 years, range 9 to 14 years; 3 Crossbreeds, 2 Poodles, 1 Boxer, Labrador Retriever and Dachshund; body condition between 7/9 and 8/9, according to Jeusette et al. (2010).
The diagnosis of PDH was based on history, physical examination, routine laboratory findings and an increased urine cortisol:creatinine ratio in two consecutive morning urine samples collected by the owner at home. After collection of the second urine sample, three doses of dexamethasone $(0.1 \mathrm{mg} / \mathrm{kg})$ were administered $\mathrm{PO}$ at 8 -hour intervals, and a third urine sample was collected the following morning, according to Kooistra and Galac (2012). The diagnosis was further supported by visualisation of the bilateral adrenal hyperplasia by ultrasonography and the pituitary mass by nuclear magnetic resonance imaging. Dogs with an infectious disease (systemic or local), pancreatitis, diabetes mellitus, hypothyroidism, tumours (except pituitary adenoma) or any other systemic disorder capable of inducing insulin resistance, or increasing TNF- $\alpha$, were excluded (Hess, 2010). Also, dog with abnormalities on complete blood count, urinalysis or biochemical profile other than those expected with PDH (stress leukogram, low urine specific gravity, mild hyperglycemia, dyslipidemia, increased alkaline phosphatase or alanine transferase), were excluded. In all cases, the common therapy used in Argentina was administered, consisting of combined treatment with cabergoline $(0.07 \mathrm{mg} / \mathrm{kg} / \mathrm{week}$, divided into doses administered every 48 hours) and ketoconazole $(15-20 \mathrm{mg} / \mathrm{kg}$ administered every 24 hours) (Castillo et al., 2008; Lien and Huang, 2008). All the dogs had a good response to the therapy, controlling the clinical signs and regularizing the biochemical alterations in less than 3 months. The dogs with HAC were euthanized $(n=5)$ when they were seriously compromised with the quality of life of the animal, product of the chronic deterioration of the disease (median survival time: 26 months, range 18 to 35 months).

Samples from control healthy dogs $(\mathrm{n}=8)$ (4 females and 4 males; median age of 7 years, range 5 to 11 years; 4 Crossbreeds, 1 Beagle, Maltese, Yorkshire Terrier; body condition between 5/9 and 6/9) were obtained during minor surgical procedures (e.g., ovariohysterectomy or exploratory laparotomy by foreign body; anesthetic protocol (acepromazinefentanyl as premedication; propofol as induction, insufluorane as maintenance; continuing infusion with remifentanyl). None of these dogs were undergoing any treatment with steroids before sampling.

\section{Immunohistochemical assay}

Visceral adipose tissue samples were fixed in 4\% buffered formol, embedded in paraffin and processed for histological examination. Slices with a $5-\mu \mathrm{m}$ thickness were made from paraffin sections of visceral fat. The sections were deparaffinised by passages in xylol and decreasing alcohol gradients. The sections were washed with PBS (pH 7.6) and permeabilised with 1x Triton X-100 (Sigma-Aldrich, Saint Louis, USA) in 
PBS. After washing, peroxidase activity was blocked with $3 \%$ hydrogen peroxide $\left(\mathrm{H}_{2} \mathrm{O}_{2}\right)$. Further washes were performed, and nonspecific binding sites were blocked with blocking serum (goat serum in PBS) for 10 minutes. Then, the samples were washed with PBS. The sections were incubated for 2 hours at $37{ }^{\circ} \mathrm{C}$ with a 1:50 dilution of a rabbit polyclonal antibody against amino acid region $65-164$ of the $11 \beta$-HSD1 enzyme (Santa Cruz Biotechnology, H-100, sc-20175) in PBS. After two washes, the Immunoperoxidase Detection System (Millipore IHC Select) was used. This system uses the avidin-biotin-peroxidase (ABC) method. Briefly, the sections were incubated for 10 minutes with the biotinylated anti-rabbit secondary antibody. After another wash, the sections were incubated for 10 minutes with horseradish peroxidase (HRP)-conjugated streptavidin and finally washed with PBS. The reaction was developed with the chromogen 3, 3'diaminobenzidine (DAB). The sections were stained with haematoxylin (as a contrast) for 5 minutes, dehydrated (with increasing alcohol gradients and xylol), and mounted with Canada balsam. In the sections used as negative controls, PBS was included in place of the primary antibody. Image analysis: the DC180 digital camera and Leica trinocular microscope model DMLS were used for image capture. The Qwin Plus software from Leica Inc. Corp. was used. Images of 30 non-consecutive fields were evaluated in each fat slice to determine the intensity of the $11 \beta$-HSD 1 immunostaining. To this end, two observers (independent from the research project) analysed the images, which were scored according to the intensity of the staining. The following values were assigned (Oberholzer et al., 1996; Ahmad et al., 2011): "0", no immunostaining; "1", weak immunolabelling; "2", moderate immunolabelling; and "3", strong immunostaining.

\section{Western blotting}

Visceral adipose tissue samples were frozen immediately at $-80^{\circ} \mathrm{C}$ until processing (10 months). The samples were homogenized in $5 \mathrm{ml}$ of Lysis Buffer (10 $\mathrm{mM}$ Tris- $\mathrm{HCl}[\mathrm{pH} 8], 1 \%$ Triton $\mathrm{X}-100$, and $0.5 \mathrm{mM}$ acetic acid) with a cocktail of protease inhibitors (25 mM HEPES, $250 \mathrm{mM}$ sucrose, $4 \mathrm{mM}$ EDTA, $1 \mu \mathrm{M}$ leupeptin, $1 \mu \mathrm{M}$ aprotinin, and $1 \mu \mathrm{M}$ pepstatin, $\mathrm{pH}$ 7.4). The homogenates were centrifuged at $12,000 \mathrm{x}$ for 10 minutes at $4{ }^{\circ} \mathrm{C}$. The supernatant was collected, and the protein concentrations were quantified using the Bradford method (Bio-Rad Laboratories) (Sapan et al., 1999). Equal amounts of protein per sample (30-40 g) were boiled for 5 minutes in Lysis Buffer (0.06 M Tris$\mathrm{HCl}$ [pH 6.8], 25\% v/v glycerol, 2\% w/v SDS, $0.01 \%$ $\mathrm{w} / \mathrm{v}$ bromophenol blue, and $5 \%$ v/v $\beta$ mercaptoethanol). Then, the proteins were subjected to polyacrylamide gel electrophoresis under denaturing conditions (SDS-PAGE) and transferred to a nitrocellulose membrane (Bio-Rad Laboratories). The membranes were blocked with $5 \%$ skim milk in $0.1 \%$ PBS-Tween (PBS-T) and incubated overnight (16 hours at $4{ }^{\circ} \mathrm{C}$, constant agitation) with a rabbit polyclonal antibody against the 65-164 amino acid region of the 11 $\beta$-HSD1 enzyme (Santa Cruz Biotechnology, H-100, sc-20175;1:200 dilution) and the G9545 rabbit anti-GAPDH antibody $(1: 100,000$ dilution). After three washes (10 minutes at room temperature) in PBS-T, the membranes were incubated for 2 hours with the HRP-conjugated anti-rabbit IgG secondary antibody (1:4000 dilution). Finally, the reaction was developed by incubating the membrane for 1 minute in a peroxidase substrate solution for enhanced chemiluminescence (ECL). The bands were digitized using the GBOX and measured with the ImageJ software (NIH, Bethesda, MD, USA). The results are normalized to the expression of a constitutive protein (GAPDH).

\section{Detection of eNOS expression in the adrenal cortex Study material}

Adrenal glands $(\mathrm{n}=18)$ : samples from dogs with HAC $(\mathrm{n}=8)$ were obtained by necropsy of patients with PDH (the same dogs previously mentioned), whereas control samples $(n=10)$ ( 5 females and 5 males; median age of 9 years, range 6 to 14 years; 5 Crossbreeds, 1 Golden Retriever, Beagle, Poodle, Pit Bull Terrier, Jack Russell; body condition between 5/9 and 7/9) were obtained by necropsy of animals euthanized for humanitarian reasons and by veterinary indication (medullary compression and polytrauma). These dogs were euthanized because they arrived at the hospital with a severe trauma, from which there was no possibility of recovery (traffic accident or fall height).

\section{Immunohistochemistry assay}

The same immunohistochemistry protocol described above was used. The sections were incubated for 2 hours at $37{ }^{\circ} \mathrm{C}$ with a 1:250 dilution of a rabbit polyclonal antibody against eNOS (Thermo Fisher Scientific, PA3-031A) in PBS. Image analysis: Images of 50 non-consecutive fields were evaluated in each adrenal cortex to determine the optical density of the cortex (zona fasciculata). The optical intensity analysis was performed after transforming the images to greyscale (8-bit). Calibration for the optical density was performed using a calibrated scale tablet ("step tablet"). The calibration curve ranged from 0 to 2.6 (optical density units) according to Oberholzer et al. (1996). Thus, the optical density value increased as the staining strength increased.

\section{Statistical analysis}

Prior to analysing the normality of the variables (D'Agostino-Pearson omnibus normality test), the experimental results were analysed using a t test (for unpaired samples, significant at $\mathrm{P}<0.05$ ) and expressed as the mean \pm SEM. To analyse $11 \beta$-HSD1 protein 
expression based on the western blotting results, oneway ANOVA and Tukey's test were performed (Graph Pad Prism 6, USA-California).

\section{Ethical approval}

The Ethics Committee of the Faculty of Veterinary Science (CICUAL) and the Office of Science at the University of Buenos Aires approved the present study according to the laws on experimentation in animals in Argentina and World Health Organization recommendations. Signed consent was obtained from the dogs' owners for participation in the present project.

\section{Results}

Visceral adipose tissue from dogs with HAC clearly express 11 $\beta$-HSD1 enzyme more than normal weighted dog (Fig. 1). Expression average score of the $11 \beta$ HSD1 enzyme was significantly higher $(\mathrm{P}=0.02)$ in the adipocytes of the visceral adipose tissues from the HAC dogs than in those from the control dogs based on the immunohistochemistry analysis (Control: $1.125 \pm$ 0.227 ; HAC: $2 \pm 0.267$ ). Likewise, $11 \beta$-HSD1 enzyme expression (Fig.2) in the adipocytes was significantly higher in the visceral adipose tissues from the dogs with HAC than in those from the control dogs based on the optical density and western blotting analysis $(\mathrm{P}=0.041)$. With respect to the eNOS enzyme (Fig.3), immunostaining of the adrenal cells from fasciculata zone showed more expression (antigen concentration) in control dogs than in HAC dogs. The optical density was significantly higher in the control dogs than in the HAC dogs $(\mathrm{P}=0.008)$ (Control: $0.824 \pm 0.047$; HAC: $0.661 \pm 0.039)$.

\section{Discussion}

In the study on visceral adipose tissue, we observed that $11 \beta$-HSD1 was expressed at higher levels in the adipocytes of dogs with HAC than in those of the control dogs. These results agree with those reported by Ahmad et al. (2011), who showed that the visceral adipose tissues of rats treated with dexamethasone had hypertrophy, hyperplasia and greater 11ß-HSD1 expression than control rats. Similarly, Morgan et al. (2014) demonstrated that glucocorticoid-treated mice

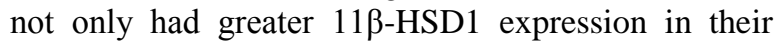
adipose and hepatic tissues than control mice but also exhibited increased enzyme activity.

The role of $11 \beta$-HSD1 in the development of HAC was first described by Tomlinson et al. (2002), who reported an extremely rare case of a PDH patient with no Cushing phenotype (no hypertension, no muscle atrophy, and no fat redistribution). These authors demonstrated that the patient had a functional defect in the 11ß-HSD1 enzyme that rendered it inactive, which correspondingly decreased the conversion of cortisone to cortisol at the local level. Later, the same enzymatic defect and the same clinical picture were described in a patient with HAC resulting from an adrenocortical nonhypophyseal tumour (Arai et al., 2008).
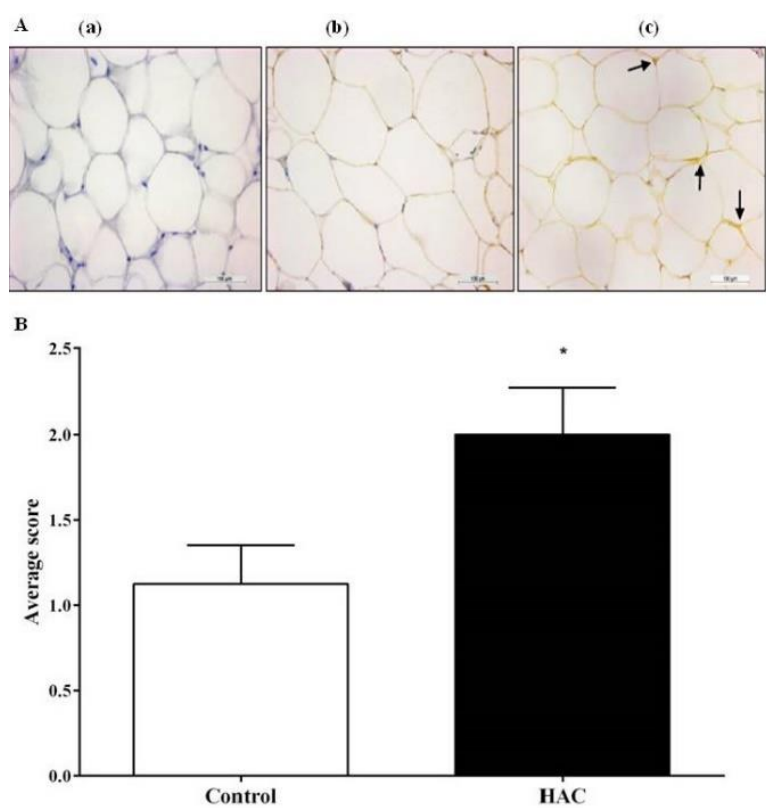

Fig. 1. Immunostaining for $11 \beta$-HSD1 (A) and Average score of 11 $\beta$-HSD1 expression (B) in dog visceral adipose tissue. (A): Negative control (a), healthy normal-weight dogs (b), dogs with HAC (c). Brown cytoplasm indicates positive labelling, whereas blue cytoplasm and nuclei are negative (haematoxylin). Arrows indicate areas with stronger staining. The scale bar is $100 \mu \mathrm{m}$. (B): Average score from HAC dogs are significantly higher $(* \mathrm{P}=0.02)$ than in control dogs. Values expressed as the mean \pm SEM.

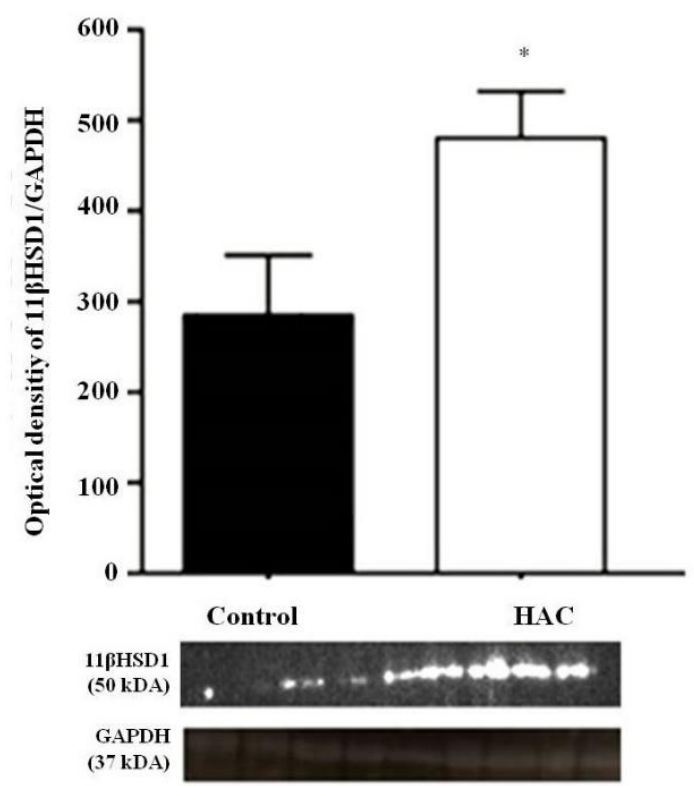

Fig. 2. 11 $\beta$-HSD1 expression in visceral adipose tissues determined optical density and western blotting in the control dogs and dogs with HAC. The enzyme are highly expressed in HAC $(* \mathrm{P}<0.05)$ according to the optical density analyse (top figure) and western blott (bottom figure). Values are expressed as the mean \pm SEM. 


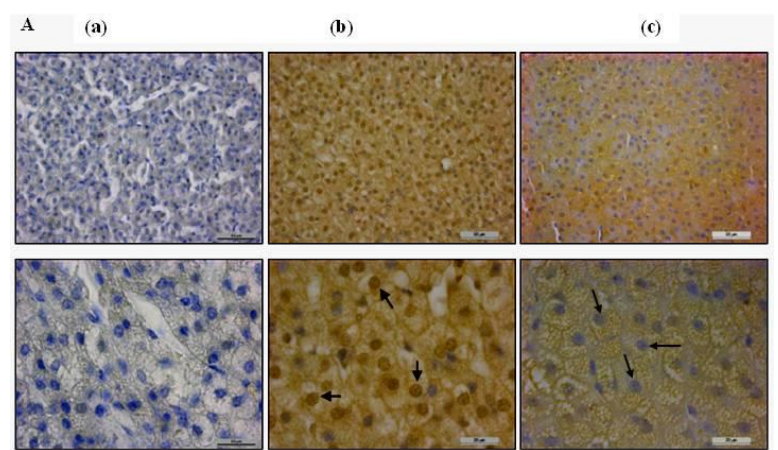

B

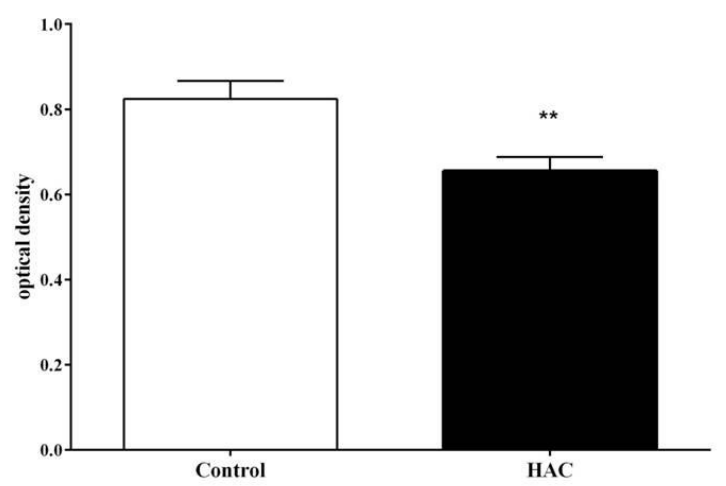

Fig. 3. Immunostaining (A) for eNOS in the adrenal cortex (zona fasciculata) and Optical density (B) of the adrenal cells (zona fasciculata). (A): Negative control (a), healthy normalweight dogs (b), dogs with HAC (c). Brown cytoplasm and nuclei indicate positive staining, whereas blue cytoplasm and nuclei are negative (haematoxylin). Arrows indicate nuclear staining. The scale bars are 50 (top figures) and $20 \mu \mathrm{m}$ (bottom figures). (B): Optical Healthy normal-weight dogs present cells with a higher optical density (greater immunostaining) than dogs with HAC $(* * \mathrm{P}<0.01)$. Values are expressed as mean \pm SEM.

Similar results were found in basic research. 11 $\beta$-HSD1 knock-out HAC model mice (in all tissues) were protected from the adverse effects of cortisol, with no hypertension, no muscle atrophy, no hepatic steatosis, and no increase in visceral fat (Morgan et al., 2014). Additionally, 11 $\beta$-HSD1 knock-out mice (adipose) were protected against hepatic steatosis, lipolysis in their adipose tissues, and excess plasma free fatty acids but did not fail to present muscular and dermal atrophy, hypertension, and deposition of visceral fat (Morgan et al., 2014). These results suggest that the local metabolism of glucocorticoids mediated by the $11 \beta$ HSD1 enzyme plays a decisive role in the development of the complications of hypercortisolism, thereby challenging the classical view that active glucocorticoids in circulation represent the most important mode of action of glucocorticoids (Morgan et al., 2016). Conversely, the local metabolism of glucocorticoids in visceral adipose tissue would play a central but by no means absolute role in the development of metabolic disturbances of hypercortisolism, especially hepatic and lipid alterations. In agreement with these results, HAC dogs in general and the dogs evaluated in this study in particular present clinical alterations typical of hypercortisolism.

Interestingly, evaluation of 11 $\beta$-HSD1 enzyme expression in the dogs by western blotting did not reveal the typical $34 \mathrm{kDa}$ and $68 \mathrm{kDa}$ bands found in humans due to the enzyme's dimeric structure (Mariniello et al., 2006). Instead, we found a single band that was $50 \mathrm{kDa}$ in size. Kannisto et al. (2004) also reported the existence of this band in human visceral adipose tissue.

Few studies have evaluated $11 \beta-H S D 1$ expression in humans with HAC. Mariniello et al. (2006) found no significant differences between 11 $\beta$-HSD1 expression in visceral adipose tissue from humans with HAC and healthy normal-weight patients. These authors postulated that the lack of an increase in 11 $\beta$-HSD1 expression in patients with HAC could be due to downregulation of the enzyme as a result of chronic overstimulation of plasma glucocorticoids.

Most studies in human medicine on obesity, metabolic syndrome, and $11 \beta$-HSD1 have argued that $11 \beta$-HSD1 is overexpressed in adipose tissues in patients with central obesity compared to control patients (PaulmyerLacroix et al., 2002; Mariniello et al., 2006; EspíndolaAntunes and Kater 2007; Candia et al., 2012), with increased local production of glucocorticoids that amplifies the effects. Iwasaki et al. (2008) postulated that metabolic syndrome would favour an intracellular Cushing state caused by overexpression of the $11 \beta$ HSD1 enzyme.

For future research, it would be interesting to develop new therapies that act specifically on $11 \beta$-HSD1 and thus be able to control hypercortisolism. Likewise, it would be interesting to evaluate if the different therapies already known for HAC act on $11 \beta$-HSD1, since it has been described that trilostane could have an effect on it (Teshima et al., 2014).

Adrenal steroidogenesis is mainly regulated by ACTH. However, numerous factors not related to ACTH play roles in the regulation of the hypothalamus-adrenalhypophysis axis (Bornstein et al., 2008). Neuropeptides, growth factors, cytokines, opioids, adipokines, bacterial ligands, and other locally produced molecules synergize or antagonize the action of ACTH (Bornstein et al., 2008; Hochol et al., 2004; Conconi et al., 2006). It is well known that NO regulates steroidogenesis in cells of the adrenal glomeruli zone (Natarajan et al., 2002), besides acting on granulosa-luteal cells of the human ovary (Van Voorhis et al., 1994) and on Leydig cells (Del Punta et al. 1996; Mondillo et al., 2009). Thus, it is postulated that dissociation between $\mathrm{ACTH}$ and the plasma 
glucocorticoid levels would occur under certain circumstances, indicating that the adrenal glands would have some "autonomy" with respect to pituitary regulation (Bornstein et al., 2008). This dissociation would occur under both physiological (Choi et al., 2007) and pathological conditions, including inflammatory processes, critical illnesses, and mental disorders (Vermes and Beishuizen, 2001; Carroll et al., 2007).

In the study on adrenal glands, we observed that the expression of the eNOS enzyme evaluated through immunohistochemistry was lower in the dogs with HAC than in the control dogs. The role of NOS in modulating the synthesis of cortisol in the adrenals has been documented and is known to be involved in the fine regulation (inhibitory) of steroidogenesis (Cymeryng et al., 1998, 2002; Repetto et al., 2010) as an intracellular autoregulatory mechanism. However, no studies have been performed in dogs with HAC for comparison with our observations. Our results support the hypothesis that the lower eNOS expression in the adrenal glands of HAC dogs could reduce the modulatory effect of $\mathrm{NO}$ on steroidogenesis, leading to insufficient inhibition of cortisol synthesis. On the other hand, it is well know that cortisol inhibits NOS leading to a decrease in NO circulating (Yang and Zhang, 2004; Liu et al., 2009; Cabrera Blatter et al., 2012). Taking this mechanism into account, hypercortisolism could reduce the expression of adrenal eNOS, and therefore, its inhibitory mechanism of steroidogenesis would be reduced.

NOS is an enzyme that has numerous cellular locations (cytosol, mitochondria, Golgi apparatus, and nucleus) that confer different functions (Oess et al., 2006). In contrast to the observations in the zona fasciculata of the adrenals of the control dogs, where immunostaining indicated strong eNOS expression in the cytoplasm and nucleus, cytoplasmic labelling and, to a lesser extent, nuclear staining was observed in the dogs with HAC. Taken together, these results not only suggest that eNOS is expressed at lower levels in the adrenals of dogs with HAC but also that the expression sites may be reduced. Cymeryng et al. $(1998,2002)$ showed that eNOS expression was increased in mouse adrenocortical tumours ( $\mathrm{Y} 1$ line) relative to normal adrenals. Therefore, evaluating eNOS expression in dogs with adrenal tumours producing HAC and the expression of the different isoenzymes in other tissues from dogs with HAC will be interesting.

In conclusion, expression of the $11 \beta$-HSD1 enzyme is increased in the visceral adipose tissues of dogs with HAC, which could favour a sustained increase in plasma cortisol in these patients. Similarly, the expression of the eNOS enzyme is decreased in the adrenal glands (zona fasciculata) of dogs with HAC, which could lead to a lack of inhibition of NO-mediated steroidogenesis. Both enzymatic alterations could intervene in the maintenance of hypercortisolism, thereby favouring the establishment and/or maintenance of the comorbidities associated with this disease.

\section{Acknowledgments}

This work was supported by a grant (code: 20720130100004BA) from University of Buenos Aires-UBACyT, Argentina.

\section{Conflict of interest}

The authors declare that there is no conflict of interests.

\section{References}

Ahmad, F., Soelaiman, I.N., Mohd Ramli, E.S., Hooi, T.N. and Suhaimi, F.H. 2011. Histomorphometric changes in the perirenal adipocytes of adrenalectomized rats treated with dexamethasone. Clinics 66(5), 849-853.

Arai, H., Kobayashi, N., Nakatsuru, Y., Masuzaki, H., Nambu, T., Takaya, K., Yamanaka, Y., Kondo, E., Yamada, G., Fujii, T., Miura, M., Komatsu, Y., Kanamoto, N., Ariyasu, H., Moriyama, K., Yasoda, A. and Nakao, K. 2008. A case of cortisol producing adrenal adenoma without phenotype of Cushing's syndrome due to impaired 11beta-hydroxysteroid dehydrogenase 1 activity. Endocr. J. 55, 709-715.

Bornstein, S.R., Engeland, W.C., Ehrhart-Bornstein, M. and Herman, J.P. 2008. Dissociation of ACTH and glucocorticoids. Trends Endocrin. Met. 19, 175-180.

Cabrera Blatter, M.F., del Prado, B., Miceli, D.D., Gomez, N., Ivanic, J., Di Tollo, B., Gallelli, M.F. and Castillo, V.A. 2012. Interleukin-6 and insulin increase and nitric oxide and adiponectin decrease in blind dogs with pituitary-dependent hyperadrenocorticism. Res. Vet. Sci. 93(3), 1195202.

Candia, R., Riquelme, A., Baudrand, R., Carvajal, C.A., Morales, M., Solís, N., Pizarro, M., Escalona, A., Carrasco, G., Boza, C., Pérez, G., Padilla, O., Cerda, J., Fardella, C.E. and Arrese, M. 2012. Overexpression of 11ß-hydroxysteroid dehydrogenase type 1 in visceral adipose tissue and portal hypercortisolism in non-alcoholic fatty liver disease. Liver Int. 32(3), 392-399.

Carroll, B.J., Cassidy, F., Naftolowitz, D., Tatham, N.E., Wilson, W.H., Iranmanesh, A., Liu, P.Y. and Veldhuis, J.D. 2007. Pathophysiology of hypercortisolism in depression. Acta Psychiatr. Scand. Suppl. 433, 90-103.

Castillo, V.A., Gomez, N.V., Lalia, J.C., Cabrera Blatter, M.F. and García, J.D. 2008. Cushing's disease in dogs: Cabergoline treatment. Res. Vet. Sci. 85, 26-34.

Chapman, K., Holmes, M. and Seckl, J. 2013. 11ßhydroxysteroid dehydrogenases: intracellular gate- 
keepers of tissue glucocorticoid action. Physiol. Rev. 93, 1139-1206.

Choi, D.C., Furay, A.R., Evanson, N.K., Ostrander, M.M., Ulrich-Lai, Y.M. and Herman, J.P. 2007. Bed nucleus of the stria terminalis subregions differentially regulate hypothalamic-pituitaryadrenal axis activity: implications for the integration of limbic inputs. J. Neurosci. 27(8), 2025-2034.

Conconi, M.T., Spinazzi, R. and Nussdorfer, G.G. 2006. Endogenous ligands of PACAP/VIP receptors in the autocrine-paracrine regulation of the adrenal gland. Int. Rev. Cytol. 249, 1-51.

Cymeryng, C.B., Dada, L.A. and Podesta, E.J. 1998. Effect of nitric oxide on rat adrenal zona fasciculata steroidogenesis. J. Endocrinol. 158, 197-203.

Cymeryng, C.B., Lotito, S.P., Colonna, C., Finkielstein, C., Pomeraniec, Y., Grión, N., Gadda, L., Maloberti, P. and Podestá, E.J. 2002. Expression of nitric oxide synthases in rat adrenal zona fasciculata cells. Endocrinology 143(4), 1235-1242.

Del Punta, K., Charreau, E.H. and Pignataro, O.P. 1996. Nitric oxide inhibits Leydig cell steroidogenesis. Endocrinology 137, 5337-5343.

Di Dalmazi, G., Pagotto, U., Pasquali, R. and Vicennati, V. 2012. Glucocorticoids and Type 2 Diabetes: From Physiology to Pathology. J. Nutr. Metab. 2012, Article ID 525093, doi:10.1155/2012/525093.

Ducsay, Ch.A. and Myers, D.A. 2011. Differential Control of Steroidogenesis by Nitric Oxide and its Adaptation with Hypoxia. J. Endocrinol. 210(3), 259-269.

Espíndola-Antunes, D. and Kater, C.E. 2007. Adipose tissue expression of 11 beta-hydroxysteroid dehydrogenase type 1 in Cushing's syndrome and in obesity. Arch. Endocrin. Metab. 51(8), 1397-1403.

Furchgott, R.F. and Zawadaki, J.V. 1980. The obligatory role of endothelial cell in the relaxation of smooth muscle by acetylcholine. Nature 288, 373-376.

Garthwaite, J. 1993. Nitric oxide signaling in the nervous system. Sem. Neuroscienc. 5, 171-180.

Hess, R.S. 2010. Insulin resistance in dogs. Vet. Clin. North. Am. Small Anim. Pract. 40, 309-316.

Hochol, A., Albertin, G., Nussdorfer, G.G., Spinazzi, R., Ziolkowska, A., Rucinski, M. and Malendowicz, L.K. 2004. Effects of neuropeptides $\mathrm{B}$ and $\mathrm{W}$ on the secretion and growth of rat adrenocortical cells. Int. J. Mol. Med. 14, 843-847.

Iwasaki, Y., Takayasu, S., Nishiyama, M., Tsugita, M., Taguchi, T., Asai, M., Yoshida, M., Kambayashi, M. and Hashimoto, K. 2008. Is the metabolic syndrome an intracellular Cushing state? Effects of multiple humoral factors on the transcriptional activity of the hepatic glucocorticoid-activating enzyme (11 $\beta$-hydroxysteroid dehydrogenase type 1) gene. Mol. Cell. Endocrinol. 285, 10-18.

Jeusette, I., Greco, D., Aquino, F., Detilleux, J., Peterson, M., Romano, V. and Torre, C. 2010. Effect of breed on body composition and comparison between various methods to estimate body composition in dogs. Res. Vet. Sci. 88, 227232.

Kannisto, K., Pietilainen, K.H., Ehrenborg, E., Rissanen, A., Kaprio, J., Hamsten, A. and YkiJarvinen, H. 2004. Overexpression of 11bhydrxysteroid dehydrogenase-1 in adipose tissue is associated with acquired obesity and features of insulin resistance: studies in young adult monozygotic twins. J. Clin. Endocr. Metab. 89, 4414-4421.

Kooistra, H.S. and Galac, S. 2012. Recent advances in the diagnosis of Cushing's syndrome in dogs. Top. Companion Anim. Med. 27, 21-24.

Lien, Y.H. and Huang, H.P. 2008. Use of ketoconazole to treat dogs with pituitary-dependent hyperadrenocorticism: 48 cases (1994-2007). J. Am. Vet. Med. Assoc. 233(12), 1896-1901.

Liu, Y., Mladinov, D., Pietrusz, J.L., Usa, K. and Liang, M. 2009. Glucocorticoid response elements and 11 beta-hydroxysteroid dehydrogenases in the regulation of endothelial nitric oxide synthase expression. Cardiovasc. Res. 81, 140-147.

Livingstone, D.E.W., Jones, G.C., Smith, K., Jamieson, P.M., Andrew, R., Kenyon, C.J. and Walker, B.R. 2000. Understanding the Role of Glucocorticoids in Obesity: Tissue-Specific Alterations of Corticosterone Metabolism in Obese Zucker Rats. Endocrinology 141, 560-563.

Loscalzo, J. 1995. Nitric oxide and vascular disease. New Engl. J. Med. 333, 251-253.

Luchi, T., Akaike, M., Mitsui, T., Ohshima, Y., Shintani, Y., Azuma, H. and Matsumoto, T. 2003. Glucocorticoid excess induces superoxide production in vascular endothelial cells and elicits vascular endothelial dysfunction. Circ. Res. 92, 8187.

Mariniello, B., Ronconi, V., Rilli, S., Bernante, P., Boscaro, M., Mantero, F. and Giacchetti, G. 2006. Adipose tissue $11 \beta$-hydroxysteroid dehydrogenase type 1 expression in obesity and Cushing's syndrome. Eur. J. Endocrinol. 155, 435-441.

Miceli, D.D., Cabrera Blatter, M.F., Gallelli, M.F., Pignataro, O.P. and Castillo, V.A. 2014. Involvement of glucagon-like peptide 1 in the glucose homeostasis regulation in obese and pituitary-dependent hyperadrenocorticism affected dogs. Res. Vet. Sci. 97(2), 211-217.

Miceli, D.D., Pignataro, O.P. and Castillo, V.A. 2017. Concurrent hyperadrenocorticism and diabetes mellitus in dogs. Res. Vet. Sci. 115, 425-431. 
Mitchell, B.M. and Webb, R.C. 2002. Impaired vasodilation and nitric oxide synthase activity in glucocorticoid-induced hypertension. Biol. Res. Nurs. 4, 16-21.

Mondillo, C., Pagotto, R.M., Piotrkowski, B., Reche, C.G., Patrignani, Z.J., Cymeryng, C.B. and Pignataro, O.P. 2009. Involvement of nitric oxide synthase in the mechanism of histamine-induced inhibition of Leydig cell steroidogenesis via histamine receptor subtypes in Sprague-Dawley rats. Biol. Reprod. 80(1), 144-152.

Morgan, S.A., McCabe, E.L., Gathercole, L.L., Hassan-Smith, Z.K., Larner, D.P., Bujalska, I.J., Stewart, P.M., Tomlinson, J.W. and Lavery, G.G. 2014. 11beta-HSD1 is the major regulator of the tissue-specific effects of circulating glucocorticoid excess. PNAS 111 E2482-E2491.

Morgan, S.A., Hassan-Smith Z.A. and Lavery G.G. 2016. Tissue-specific activation of cortisol in Cushing's syndrome. Eur. J. Endocrinol. 175(2), R83-9.

Morton, N.M. and Seckl, J.R. 2008. 11betahydroxysteroid dehydrogenase type 1 and obesity. Front. Horm. Res. 36, 146-164.

Natarajan, R., Yang, D., Lanting, L. and Nadler, J. 2002. Key role of P38 mitogen-activated protein kinase and the lipoxygenase pathway in angiotensin II actions in H295R adrenocortical cells. Endocrine 18(3), 295-301.

Nathan, C., 1992. Nitric oxide as a secretory product of mammalian cells. FASEB J. 6(12), 3051-3064.

Oberholzer, M., Ostreicher, M., Christen, H. and Bruhlmann, M. 1996. Methods in quantitative image analysis. Histochem. Cell. Biol. 105, 333355.

Oess, S., Icking, A., Fulton, D., Govers, D. and MullerEsterl, W. 2006. Subcellular targeting and trafficking of nitric oxide synthases. Biochem. J. 396, 401-409.

Palmer, R.M., Ferrige, A.G. and Mocada, S. 1987. Nitric oxide release acconts for the biological activity of endothelium - derived relaxing factor. Nature 327, 524-526.

Palmer, R.M., Ashton, D.S. and Moncada, S. 1988. Vascular endothelial cells synthesize nitric oxide from L-arginine. Nature (Long) 333, 664-666.

Paradise, W.A., Vesper, B.J., Goel, A., Waltonen, J.D., Altman, K.W., Haines, G.K. and Radosevich, J.A. 2010. Nitric oxide: perspectives and emerging studies of a well known cytotoxin. Int. J. Mol. Sci. 11(7), 2715-2745.

Paulmyer-Lacroix, O., Boullu, S., Oliver, C., Alessi, M.C. and Grino, M. 2002. Expression of the mRNA Coding for 11ß-Hydroxysteroid Dehydrogenase Type 1 in Adipose Tissue from Obese Patients: An in Situ Hybridization Study. J. Clin. Endocr. Metab. 87, 2701-2705.

Pivonello, R., De Leo, M., Vitale, P., Cozzolino, A., Simeoli, Ch., De Martino, M.C., Lombardi, G. and Colao, A. 2010. Pathophysiology of Diabetes Mellitus in Cushing's Syndrome. Neuroendocrinology 92, 77-81.

Repetto, E.M., Sanchez, R., Cipelli, J., Astort, F., Calejman, C.M., Piroli, G.G., Arias, P. and Cymeryng, C.B. 2010. Dysregulation of Corticosterone Secretion in Streptozotocin-Diabetic Rats: Modulatory Role of the Adrenocortical Nitrergic System. Endocrinology 151(1), 203-210.

Ryan, V.H., Trayhurn, P., Hunter, L., Morris, P.J. and German, A.J. 2011. 11-Hydroxy--steroid dehydrogenase gene expression in canine adipose tissue and adipocytes: Stimulation by lipopolysaccharide and tumor necrosis factor. Dom. Anim. Endocr. 41, 150-161.

Sapan, C.V., Lundblad, R.L. and Price, N.C. 1999. Colorimetric protein assay techniques. Biotechnol. Appl. Biochem. 29(2), 99-108.

Seckl, J.R. and Walker, B.R. 2001. Minireview: 11ßHydroxysteroid Dehydrogenase Type 1- A TissueSpecific Amplifier of Glucocorticoid Action. Endocrinology 142(4), 1371-1376.

Sessa, W.C. 1994. The nitric oxide synthase family of proteins. J. Vasc. Res. 31(3), 131-143.

Sieber-Ruckstuhl, N.S., Meli, M.L., Boretti, F.S., Gönczi, E., Lutz, H. and Reusch, C.E. 2007. Quantitative real-time PCR for the measurement of 11beta-HSD1 and 11beta-HSD2 mRNA levels in tissues of healthy dogs. Horm. Metab. Res. 39(8), 548-554.

Stulnig, T.M. and Waldhausl, W. 2004. 11ßHydroxysteroid dehydrogenase Type 1 in obesity and Type 2 diabetes. Diabetologia 47, 1-11.

Teshima, T., Matsumoto, H., Kumagai, T., Kurano, M. and Koyama, H. 2014. Expression of $11 \beta-$ hydroxysteroid dehydrogenase isoforms in canine adrenal glands treated with trilostane. Vet. J. 200, 452-455.

Tomlinson, J.W., Draper, N., Mackie, J., Johnson, A.P., Holder, G., Wood, P. and Stewart, P.M. 2002. Absence of Cushingoid phenotype in a patient with Cushing's disease due to defective cortisone to cortisol conversion. J. Clin. Endocr. Metab. 87, 5762.

Tomlinson, J.W., Walker, E.A., Bujalska, I.J., Draper, N., Lavery, G.G., Cooper, M.S., Hewison, M. and Stewart, P.M. 2004. 11beta-hydroxysteroid dehydrogenase type 1: a tissue-specific regulator of glucocorticoid response. Endocr. Rev. 25, 831-866.

Van Voorhis, B.J., Dunn, M.S., Snyder, G.D. and Weiner, C.P. 1994. Nitric oxide: an autocrine 
regulator of human granulosa-luteal cell steroidogenesis. Endocrinology 135(5), 1799-1806.

Vermes, I. and Beishuizen, A. 2001. The hypothalamicpituitary-adrenal response to critical illness. Best Pract. Res. Clin. Endocrinol. Metab. 15, 495-511.

Wake, D.J. and Walker, B.R. 2004. 11ßHydroxysteroid dehydrogenase type 1 in obesity and the metabolic syndrome. Mol. Cell. Endocrinol.
$215,45-54$.

Walker, B.R. and Andrew, R. 2006. Tissue production of cortisol by 11beta-hydroxysteroid dehydrogenase type 1 and metabolic disease. Ann. NY Acad. Sci. 1083, 165-184.

Yang, S. and Zhang, L. 2004. Glucocorticoids and vascular reactivity. Curr. Vasc. Pharmacol. 2(1), 112. 